\title{
Expression of Amphetamine-Induced Behavioral Sensitization after Short- and Long-Term Withdrawal Periods: Participation of $\mu$ - and $\delta$-Opioid Receptors
}

\author{
Karin Magendzo*,' and Gonzalo Bustos' \\ 'Laboratory of Biochemical Pharmacology, Department of Cellular and Molecular Biology, Faculty of Biological Sciences, Catholic University of \\ Chile, Santiago, Chile
}

\begin{abstract}
Repeated amphetamine administration results in behavioral sensitization, an enduring behavioral transformation expressed after short and long periods of withdrawal. To investigate the participation of the opioid system in amphetamine-induced behavioral sensitization, we studied the effect of naloxone, an opioid receptor antagonist, on the expression of behavioral sensitization tested after short- (2 days) and long-term ( 14 days) withdrawal periods. In addition, using quantitative competitive RT-PCR, we examined the levels of $\mu$-opioid receptor (MOR) and $\delta$-opioid receptor (DOR) mRNA in the nucleus accumbens shell (NAcSh) and ventral tegmental area (VTA) of behaviorally sensitized rats, at these two withdrawal times. This study showed that whereas naloxone did not modify the expression of behavioral sensitization tested after 2 days of withdrawal, it completely blocked the expression when tested after 14 days of withdrawal. DOR and MOR mRNA levels were not modified in the NAcSh of rats expressing behavioral sensitization after 2 or 14 days of withdrawal. Conversely, DOR and MOR mRNA levels were elevated in the VTA of animals expressing behavioral sensitization after 2 days of withdrawal. However, whereas DOR mRNA returned to control levels, MOR mRNA levels remained elevated in animals expressing behavioral sensitization after 14 days of withdrawal. These results indicate a striking difference between the role played by opioid receptors in the expression of amphetamine-induced behavioral sensitization, when tested after short- or long-term withdrawal periods. In addition, our results support the notion that repeated amphetamine-induced changes in opioid receptor expression may contribute to the perpetuation of psychostimulant abuse and/or relapse.
\end{abstract}

Neuropsychopharmacology (2003) 28, 468-477. doi:I0.1038/sj.npp. 1300063

Keywords: addiction; opioid receptors; naloxone; ventral tegmental area; nucleus accumbens shell; competitive quantitative RT-PCR

\section{INTRODUCTION}

Drug addiction is a pathological behavior characterized by compulsive drug seeking and drug taking, despite severe adverse consequences. A key feature of addiction is the intensification of drug craving that occurs in human addicts with repeated drug exposure. This intensification is long lasting and can persist after years and even decades of abstinence, leading to a very high incidence of relapse. A prominent animal model for this persistent behavioral change is the long-lasting increase in locomotor response to drugs of abuse following repeated exposure. This increased

\footnotetext{
*Correspondence: Dr K Magendzo, Laboratory of Biochemical Pharmacology, Department of Cellular and Molecular Biology, Faculty of Biological Sciences, Catholic University of Chile, Alameda 340, PO Box I |4-D, Santiago, Chile, Tel: +562 686 2654, Fax: +562 686 2660, E-mail: kmagendz@genes.bio.puc.cl

Received 2 May 2002; revised 6 September 2002; accepted 10 September 2002

Online publication: 13 September 2002 at http://www.acnp.org/ citations/Npp09/302377
}

response, termed behavioral sensitization, is thought to reflect plastic changes in neuronal circuits that determine the incentive value of external stimuli, rendering the circuits hypersensitive or sensitized (Kalivas et al, 1998; Robinson and Berridge, 2000).

Many of the changes that have been identified following repeated psychostimulant administration take place in the mesolimbic dopamine system, major components of which are the ventral tegmental area (VTA) and the nucleus accumbens (NAc). Rats repeatedly exposed to psychostimulants have consistently shown augmented dopaminergic transmission in the NAc, preferentially in the shell region (NAcSh) (Pierce and Kalivas, 1995). Despite its evident importance, however, dopaminergic neurotransmission is only one component of the neural circuitry, termed the motive circuit, that mediates behavioral sensitization to psychostimulants (Pierce and Kalivas, 1997).

Another neurotransmitter system known to be implicated in behavioral sensitization is the excitatory amino acid system (Wolf, 1998; Vanderschuren and Kalivas, 2000). Glutamate receptor antagonists, as well as excitotoxic 
lesions of the prefrontal cortex (PFC), can block the development of behavioral sensitization to psychostimulants (Karler et al, 1989, 1994; Wolf and Khansa, 1991; Kalivas and Alesdatter, 1993; Schenk et al, 1993; Stewart and Druhan, 1993; Wolf and Jeziorski, 1993; Ohmori et al, 1994; Wolf et al, 1995; Cador et al, 1999). Moreover, release of glutamate in the NAc and VTA is enhanced in amphetamine-sensitized rats (Xue et al, 1996; Wolf and Xue, 1998, 1999; Wolf et al, 2000).

The opioid system, one of the neuronal systems that constitute the motive circuit, has been recognized for its involvement in locomotor as well as motivational and emotional behaviors (Di Chiara and North, 1992; Shippenberg and Elmer, 1998). Anatomical and neurochemical evidence support the interaction between the opioidergic and dopaminergic systems within the motive circuit (Di Chiara and Imperato, 1988; Devine et al, 1993; Churchill and Kalivas, 1996; Feigenbaum and Howard, 1997; Svingos et al, 1996, 1998, 1999, 2001; Garzon and Pickel, 2001). In addition, in several different animal models of drug reinforcement, opioid receptor antagonists have been shown to attenuate the rewarding effects of psychostimulants (Menkens et al, 1992; Sala et al, 1995; Kuzmin et al, 1997).

More recently, evidence supporting the interaction between the opioidergic and glutamatergic neuronal systems within the motive circuit has started to emerge. Electron microscopy studies in the VTA reveal the presence of $\mu$-opioid receptors (MOR) on axon terminals forming excitatory synapses (Garzon and Pickel, 2001) and on inhibitory neurons projecting to the medial PFC (Svingos et $a l, 2001)$. In the NAc, NMDA receptors colocalize with MOR (Gracy et al, 1997), and immunoreactive profiles for MOR and $\delta$-opioid receptors (DOR) are associated with excitatory synapses (Svingos et al, 1996, 1998). In addition, MOR activation in the NAc modulates NMDA-induced currents (Martin et al, 1997) and activation of DOR in the striatum modulates the increase in calcium-dependent, amphetamine-evoked, glutamate extracellular levels (Rawls and McGinty, 2000).

Numerous reports support the evidence that psychostimulants affect the expression and function of opioid receptors within the nuclei of the motive circuit. Cocaine administered to various species, using many different treatment regimens, induced changes in the expression of opioid receptors and opioid-induced inhibition of adenylyl cyclase (Unterwald, 2001). Based on this evidence, various investigators have studied the involvement of the endogenous opioid system in psychostimulant-induced behavioral sensitization. It is currently well established that the endogenous $\kappa$-opioid system plays an important role in opposing behavioral alterations that occur as a consequence of repeated psychostimulant administration, including the initiation and long-term expression of behavioral sensitization (Shippenberg et al, 2001). On the other hand, information regarding the role of MOR and DOR in behavioral sensitization is scarce. We and others have reported changes in the expression levels of MOR in the NAc and other nuclei of the motive circuit, after intermittent injections of amphetamine or cocaine that induce behavioral sensitization (Unterwald et al, 1992, 1994, 2001; Vecchiola et al, 1999). Opioid-receptor-coupled adenylate cyclase activity was also found to be altered after repeated intermittent injections of cocaine (Sala et al, 1995; Unterwald et al, 1993; Unterwald and Cuntapay, 2000). In addition, the opioid antagonist naltrexone blocks the induction of amphetamine and cocaine-induced behavioral sensitization (Balcells-Olivero and Vezina, 1997; Sala et al, 1995), and Heidbreder et al (1996) reported the involvement of DOR in the induction but not the expression of cocaineinduced behavioral sensitization measured after a shortterm withdrawal period.

At present no studies have been done to show the participation of MOR and DOR after long-term withdrawal periods. The difference in withdrawal times is an important point to consider since sensitization occurs because of a time-dependent cascade of different cellular changes and, thus, the neuronal events accompanying locomotor sensitization differ between short- and long-term withdrawal periods (Pierce and Kalivas, 1997; White and Kalivas, 1998; Wolf, 1998; Vanderschuren and Kalivas, 2000).

In the present study, we have investigated the involvement of opioid receptors in the expression of amphetamineinduced behavioral sensitization measured after short (2 days) and long (14 days) periods of withdrawal. In addition, we examined MOR and DOR mRNA levels in the NAcSh and VTA of rats expressing behavioral sensitization at these two stages of withdrawal.

\section{METHODS}

\section{Drugs and Chemicals}

D-Amphetamine was obtained from Laboratorios Chile (Santiago, Chile). Naloxone hydrochloride was from Research Biochemicals International (RBI; Natick, MA, USA). Chomczynski Reagent was from Winkler (Santiago, Chile). Random primers were obtained from Promega (Madison, WI, USA). Other reagents used for in vitro transcription, reverse transcription and $\mathrm{PCR}$, as well as ethidium bromide and agarose, were from Gibco-BRL (Bethesda, MD, USA).

\section{Animals}

All procedures were in strict accordance with the National Institutes of Health Guide for the Care and Use of Laboratory Animals. Male Sprague-Dawley rats (Taconic, Germantown, NY, USA) were individually housed in the testing room maintained at constant temperature with a $12 \mathrm{~h}$ light/dark cycle. Food and water were available ad libitum except during locomotor testing. Rats (130-170 g) were allowed 1 week of habituation before any treatment began, at which time they had reached a weight of 190-230 g. All experiments were performed during the animals' light cycle.

\section{Amphetamine Dosing Paradigm}

The induction of behavioral sensitization consisted of four injections of amphetamine $(1.5 \mathrm{mg} / \mathrm{kg}$, i.p.) or saline $(0.9 \%$ $\mathrm{NaCl}, 1 \mathrm{ml} / \mathrm{kg}$, i.p.), administered once every other day. All injections were performed by the same experimenter, between 12:00 and 1:00 pm.

The expression of behavioral sensitization was tested on 2 days: the first (challenge 1), 2 days following the last 
Table I Different experimental groups and injections administered during the induction and expression of behavioral sensitization

\begin{tabular}{llll}
\hline Drug exposure & amph/amph & sal/amph & sal/sal \\
\hline Induction of sensitization & amph $(1.5 \mathrm{mg} / \mathrm{kg})$ & $\mathrm{sal}$ & $\mathrm{sal}$ \\
Repeated injections I-4 & & & \\
& & amph $(1.5 \mathrm{mg} / \mathrm{kg})$ & $\mathrm{sal}$ \\
Expression of sensitization & amph $(1.5 \mathrm{mg} / \mathrm{kg})$ & amph $(0.75 \mathrm{mg} / \mathrm{kg})$ & $\mathrm{sal}$ \\
Challenge I (2 days withdrawal) & amph $(0.75 \mathrm{mg} / \mathrm{kg})$ & \\
Challenge 2 (I4 days withdrawal) & &
\end{tabular}

Table 2 Different experimental groups and injections administered during the induction and expression of behavioral sensitization in the presence or absence of naloxone

\begin{tabular}{|c|c|c|c|c|c|c|}
\hline Drug exposure & amph/amph & amph/amph+NLX & sal/amph & sal/amph+NLX & sal/sal & sal/sal+NLX \\
\hline $\begin{array}{l}\text { Expression of sensitization } \\
\text { Challenge I } \\
\text { ( } 2 \text { days withdrawal) }\end{array}$ & amph $(1.5 \mathrm{mg} / \mathrm{kg})+\mathrm{sal}$ & amph $(1.5 \mathrm{mg} / \mathrm{kg})+\mathrm{NLX}$ & 10 & 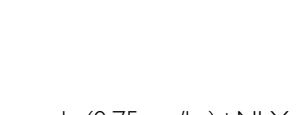 & sal & sal+NLX \\
\hline $\begin{array}{l}\text { Challenge } 2 \\
\text { ( } 14 \text { days withdrawal) }\end{array}$ & amph $(0.75 \mathrm{mg} / \mathrm{kg})+\mathrm{NLX}$ & amph $(0.75 \mathrm{mg} / \mathrm{kg})+\mathrm{sal}$ & amph $(0.75 \mathrm{mg} / \mathrm{kg})+\mathrm{sal}$ & amph $(0.75 \mathrm{mg} / \mathrm{kg})+\mathrm{NLX}$ & & \\
\hline
\end{tabular}

induction injection, and the second (challenge 2), 14-15 days following the last induction injection. Table 1 shows the different experimental groups and the injections administered during the induction phase and the test for expression days.

\section{Naloxone Treatment}

Induction of sensitization was performed as described above. On the first test for expression of sensitization (2 days withdrawal), each group of animals was randomly divided in two: the saline-pretreated group received a saline injection preceded $10 \mathrm{~min}$ earlier by saline or naloxone $(5 \mathrm{mg} / \mathrm{kg}$, i.p.); the amphetamine-pretreated groups received an amphetamine challenge $(1.5 \mathrm{mg} / \mathrm{kg}$, i.p.) preceded $10 \mathrm{~min}$ earlier by saline or naloxone $(5 \mathrm{mg} / \mathrm{kg}$, i.p.). On the second test for expression of sensitization (14 days withdrawal) all groups of rats received a challenge injection of amphetamine $(0.75 \mathrm{mg} / \mathrm{kg}$, i.p. $)$, administered $10 \mathrm{~min}$ after saline or naloxone $(5 \mathrm{mg} / \mathrm{kg}$, i.p.). Table 2 shows the different experimental groups and the injections administered during the induction phase and the test for expression days.

\section{Locomotor Testing}

Test sessions began with $1 \mathrm{~h}$ habituation to the locomotor testing cage, consisting of a $15 \times 47 \times 26 \mathrm{~cm}^{3}$ cage equipped with two pairs of infrared lights located lengthwise, $5 \mathrm{~cm}$ above the floor, $25 \mathrm{~cm}$ apart. Test cages were identical to the home cages except that the floors were covered with stainlesssteel grids instead of wood shaving. Crossovers, which register upon breaking of consecutive photobeams, were used as a measure of horizontal locomotor activity. Stereotypy was not quantified because the primary behavior elicited by $1.5 \mathrm{mg} / \mathrm{kg}$ D-amphetamine injected i.p. was cage crossing, with some rearing performed at either end of the cage.

After the habituation period, rats were given an intraperitoneal injection of amphetamine or saline, and immediately returned to the test cages. Horizontal locomotor activity was monitored during the next $2 \mathrm{~h}$. Following the testing period, animals were returned to their home cages.

\section{Dissection of Brain Regions and Preparation of Total RNA}

After the last locomotor testing session, rats were decapitated, brains rapidly removed and sectioned in coronal slices using an ice-cold rodent brain mold (ASI Instruments, Warren, MI). Coronal slices were frozen on microscope slides that were placed on top of a metal block in a dry ice/ethanol bath. Frozen coronal sections were stored at $-80^{\circ} \mathrm{C}$ until dissection. To minimize variability between time of drug treatment and animal sacrifice, rats from each experimental group (three groups, five rats per group) were sacrificed sequentially in a fixed interval of $8 \mathrm{~min}$. Two separate experiments of 15 rats each were carried out for both the short and long withdrawal periods, in order to work with a maximum of 15 rats at a time.

Nucleus accumbens shell (NAcSh) and VTA were dissected by means of a micropuncher ( $1 \mathrm{~mm}$ diameter, kind gift of $\mathrm{Dr}$ Miklos Palkovits, NIMH, NIH, Bethesda, MD, USA), from 1or 2-mm thick frozen coronal slices, respectively (approximate coordinates: bregma $0.7-1.7$ for NAcSh and -4.8 to -6.8 for VTA). Total RNA was purified from dissected brain regions pooled from two to three brains, using Chomczynski Reagent and following the manufacturer's recommendations. Total RNA concentration was determined by spectrophotometer measurements at $260 \mathrm{~nm}$.

\section{Competitive Quantitative RT-PCR}

Competitor RNA was obtained by in vitro transcription of plasmids containing deleted PCR fragments of MOR and DOR cDNA, kindly provided by Dr Beata Búzás (Uniformed Services University, Bethesda, MD, USA). Competitive quantitative RT-PCR was carried out by a modification of 
the method described by Búzás and Cox (1997). Reverse transcription was performed on $35 \mathrm{ng}$ of total RNA and varying amounts of competitor RNA (0.2 log difference between each tube; five tubes/sample). Reverse transcription reaction components and incubation conditions, and PCR reagents and primers, were as described (Búzás and Cox, 1997). PCR was performed on an MJ Research thermocycler with the following conditions: after an initial 5 min incubation at $95^{\circ} \mathrm{C}$, amplification was carried out for 30 cycles at $95 \mathrm{C}^{\circ}$ for $30 \mathrm{~s}, 58^{\circ} \mathrm{C}$ for $30 \mathrm{~s}$, and $72^{\circ} \mathrm{C}$ for $30 \mathrm{~s}$. The last primer extension step was at $72^{\circ} \mathrm{C}$ for $7 \mathrm{~min}$.

\section{Separation, Detection, and Quantification of PCR Products}

A total of $10 \mu \mathrm{l}$ of amplified products was separated on a $2 \%$ agarose gel, visualized by ethidium bromide staining under UV illumination and photographed using a Polaroid 57 type film. Photographs were scanned and the intensity of the bands was quantified using the UNSCAN-IT computer program.

For analyzing the results, the log of the ratio of pixels of target to competitor PCR bands was graphed as a function of the log of a known amount of competitor RNA added to the correspondent RT reaction. The GraphPad Prism 2.01 software was used for regression analysis and calculation of $x$-intercepts, which corresponds to the points at which the molar ratio of the target and competitor RNAs is equal.

\section{Statistical Analysis}

All statistical analysis was performed using Prism 2.01 GraphPad Software. Horizontal locomotor activity across test sessions was first analyzed by two-way ANOVA (treatment $\times$ test day). Group differences on individual test days were assessed by one-way ANOVA followed by the Newman-Keuls Multiple Comparison Test (when three groups were analyzed) or by the Mann-Whitney U-test (when two groups were analyzed). Differences between groups on the same test day were assessed by one-way ANOVA followed by the Newman-Keuls Multiple Compar- ison Test. The number of copies of opioid receptor mRNA was analyzed by one-way ANOVA followed by the Newmann-Keuls Multiple Comparison Test. All data are reported as means+SEM.

\section{RESULTS}

\section{Induction and Expression of Behavioral Sensitization}

To induce behavioral sensitization, repeated amphetamine $(1.5 \mathrm{mg} / \mathrm{kg}$, i.p.) injections were paired with exposure of the animals to a distinct test environment. An acute injection of amphetamine administered on test session 1 produces an increase in the horizontal locomotor response (Figure 1; total crossovers during $120 \mathrm{~min}$; test session 1: amph/amph, $25+5, n=5 ; \mathrm{sal} / \mathrm{sal}, 8+2, n=5 ; p<0.05)$. The horizontal locomotor response to a fixed dose of amphetamine $(1.5 \mathrm{mg} / \mathrm{kg}$, i.p.) increased from test session 1 to test session 4 (Figure 1; test session 1: amph/amph, $25+5, n=5$; test session 4: amph/amph, $62+7, n=5 ; p<0.01)$. No significant difference in the horizontal locomotor response was observed across test sessions in the saline control animals (Figure 1; test session 1: sal/sal $8+2, n=5$; test session 4: sal/ sal, $6+3, n=5$ ).

Expression of behavioral sensitization was observed in response to an amphetamine challenge injection administered to amphetamine-pretreated animals after 2 days and 14 days of withdrawal (Figure 1; chall. 1: amph/amph, 66+6, $n=4$; sal/amph, $49+6, n=4, p<0.05$; chall. $2:$ amph/amph, $44+11, n=4$; sal/amph, $8+1, n=4, p<0.05)$. No significant increase in locomotor activity was observed in the saline control animals (Figure 1; chall. 1: sal/sal, $5+1, n=4$; chall. 2: sal/sal, $5+1, n=4)$.

Effect of Naloxone on the Expression of AmphetamineInduced Behavioral Sensitization Measured 2 and 14 Days after Repeated Amphetamine Administration

To determine whether opioid receptors participate in the expression of amphetamine-induced behavioral sensitization, naloxone (5 mg/kg, i.p.), a selective, nonspecific opioid

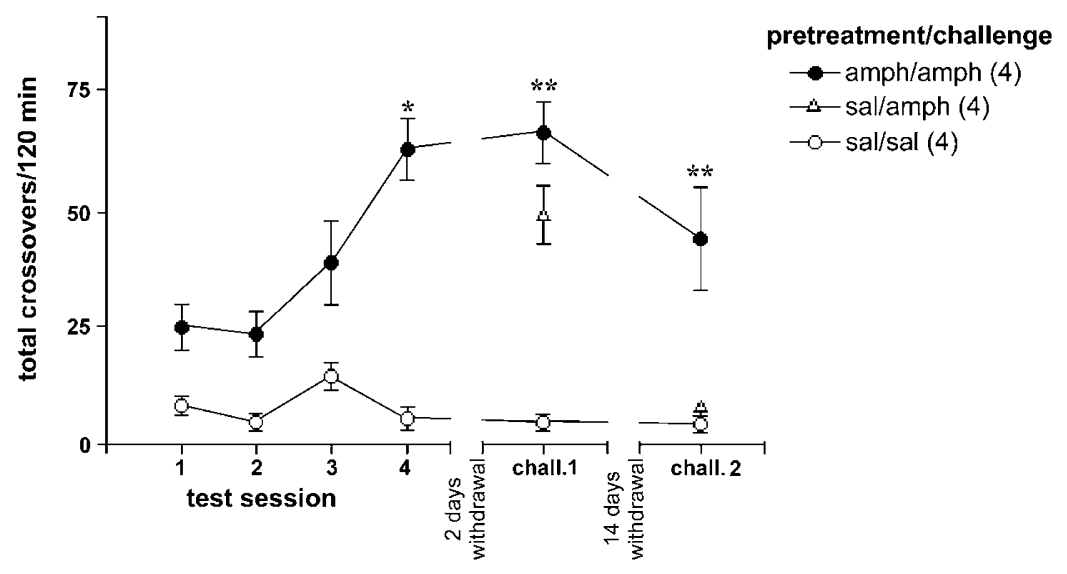

Figure I Induction and expression of behavioral sensitization produced by repeated amphetamine administration. Values are expressed as mean \pm SEM number of crossovers achieved during $120 \mathrm{~min}$, in response to saline (sal) or amphetamine (amph) injections. Pretreatment consisted of four injections of sal $(\mathrm{I} \mathrm{ml} / \mathrm{kg})$ or amph $(1.5 \mathrm{mg} / \mathrm{ml} / \mathrm{kg})$ administered once every other day. Amph challenge injections were administered after two (chall. I; $1.5 \mathrm{mg} / \mathrm{kg})$ and I4 (chall. 2; $0.75 \mathrm{mg} / \mathrm{kg}$ ) days of withdrawal. The number of rats in the different groups are given in parentheses in the symbol legend. $* p<0.0 \mathrm{l}$, compared to test session I; ${ }^{* *} p<0.05$, compared to sal/amph control group. 
receptor antagonist, was injected $10 \mathrm{~min}$ before a saline or amphetamine challenge injection administered to pretreated rats 2 or 14 days after withdrawal.

The expression of behavioral sensitization tested after 2 days of withdrawal was not significantly affected by naloxone (Figure 2a; total crossovers during $120 \mathrm{~min}$, amph/amph, $128+26, n=4$; amph/amph+NLX, 109+36, $n=4)$. In addition, no significant difference was observed between the locomotor activity induced by a saline challenge injection in the presence or absence of naloxone (Figure 2a; sal/sal, $10+3, n=5$; sal/sal+NLX, $8+5, n=5$ ).

On the other hand, naloxone completely blocked the expression of behavioral sensitization when tested 2 weeks after withdrawal (Figure 2b; amph/amph, 93+16, $n=4$; amph/amph+NLX, 29+12, $n=4 ; p<0.05)$, whereas the locomotor activity induced by an amphetamine challenge injection administered to saline-pretreated rats was not affected by naloxone (sal/amph, 27+11, $n=4$; sal/ amph+NLX, 25+5, $n=4)$.

\section{Quantification of MOR and DOR mRNA Levels Expressed in NAcSh and VTA of Rats Expressing Behavioral Sensitization after Short- and Long-Term Withdrawal Periods}

The levels of DOR and MOR mRNA, expressed in the NAcSh and VTA, were quantified in order to investigate whether changes in opioid receptor mRNA levels could account for the difference in the role played by opioid receptors in the expression of behavioral sensitization when tested 2 or 14 days after withdrawal. Only animals that showed behavioral sensitization were considered for analysis.

DOR and MOR mRNA levels were quantified by competitive RT-PCR, as described under Methods. Figure 3 shows two representative photographs of gels loaded with the five RT-PCR reactions performed for each RNA sample (left panel), and their correspondent densitometric analysis curves (right panel).

No significant changes were observed in the levels of DOR or MOR mRNAs expressed in the NAcSh of behaviorally sensitized rats, tested 2 or 14 days after withdrawal (Figure $4 \mathrm{a}$; copies DOR mRNA (\%)/ng total RNA; 2 days withdrawal: sal/ sal, $100+7.8, n=4 ;$ amph/amph, $106+3.8, n=5 ; 14$ days withdrawal: sal/sal, $100+19.0, n=3$; sal/amph, $99.5+3.4, n=4$; amph/amph, 82.7+9.2, $n=4$; Figure $4 \mathrm{~b}$; copies MOR mRNA (\%)/ng total RNA; 2 days withdrawal: sal/sal, $100+11.2, n=4$; amph/amph, $116+9.6, n=5 ; 14$ days withdrawal: sal/sal, $100+14.4, n=3$; amph/amph, 91.5+14.0, $n=4)$.

On the other hand, a significant increase in both DOR and MOR mRNA levels was observed in the VTA of rats expressing behaviorally sensitization when tested after 2 days of withdrawal (Figure 5a; copies DOR mRNA (\%)/ng total RNA, sal/sal, $100+22.7, n=3$; amph/amph, 192.7+36.1, a

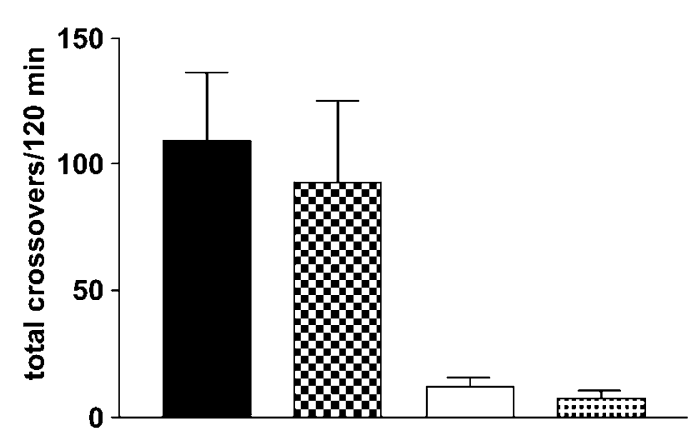

b b 14 days withdrawal

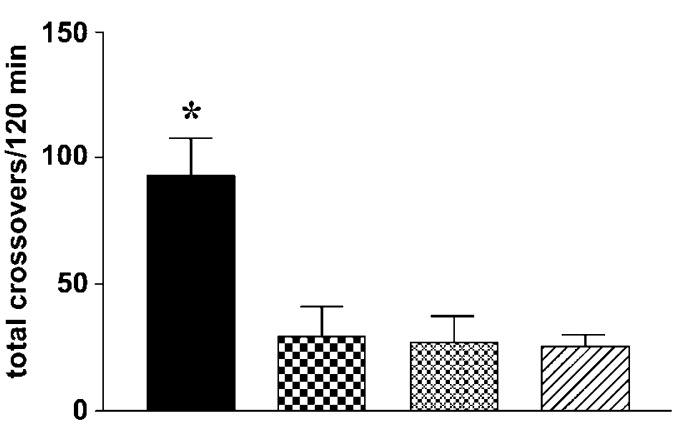

pretreatment/challenge

amph/amph (4)

amph/amph+NLX (4)

$\square \mathrm{sal} / \mathrm{sal}(5)$

․ㅠㄹㅛ sal/sal+NLX (5)

\author{
pretreatment/challenge \\ amph/amph (4) \\ 50 amph/amph+NLX (4) \\ «al/amph (4) \\ $\mathrm{E}$ Zu sal/amph+NLX (4)
}

Figure 2 Effect of naloxone on the expression of behavioral sensitization tested 2 and 14 days after withdrawal. Values are expressed as mean \pm SEM number of crossovers achieved during $120 \mathrm{~min}$, in response to challenge injections. Pretreatment consisted of four injections of saline (sal; I $\mathrm{ml} / \mathrm{kg}$ ) or amphetamine (amph; $1.5 \mathrm{mg} / \mathrm{kg}$ ), administered once every other day. (a) After 2 days of withdrawal, challenge injections of amph ( $1.5 \mathrm{mg} / \mathrm{kg}$ ) or sal were administered in the presence or absence of naloxone (NLX; $5 \mathrm{mg} / \mathrm{kg}$ ). (b) After I4 days of withdrawal, all rats received an amphetamine challenge injection $(0.75 \mathrm{mg} / \mathrm{kg})$, administered in the presence or absence of naloxone. The number of rats in the different groups are given in parentheses in the symbol legend. $* p<0.05$. 

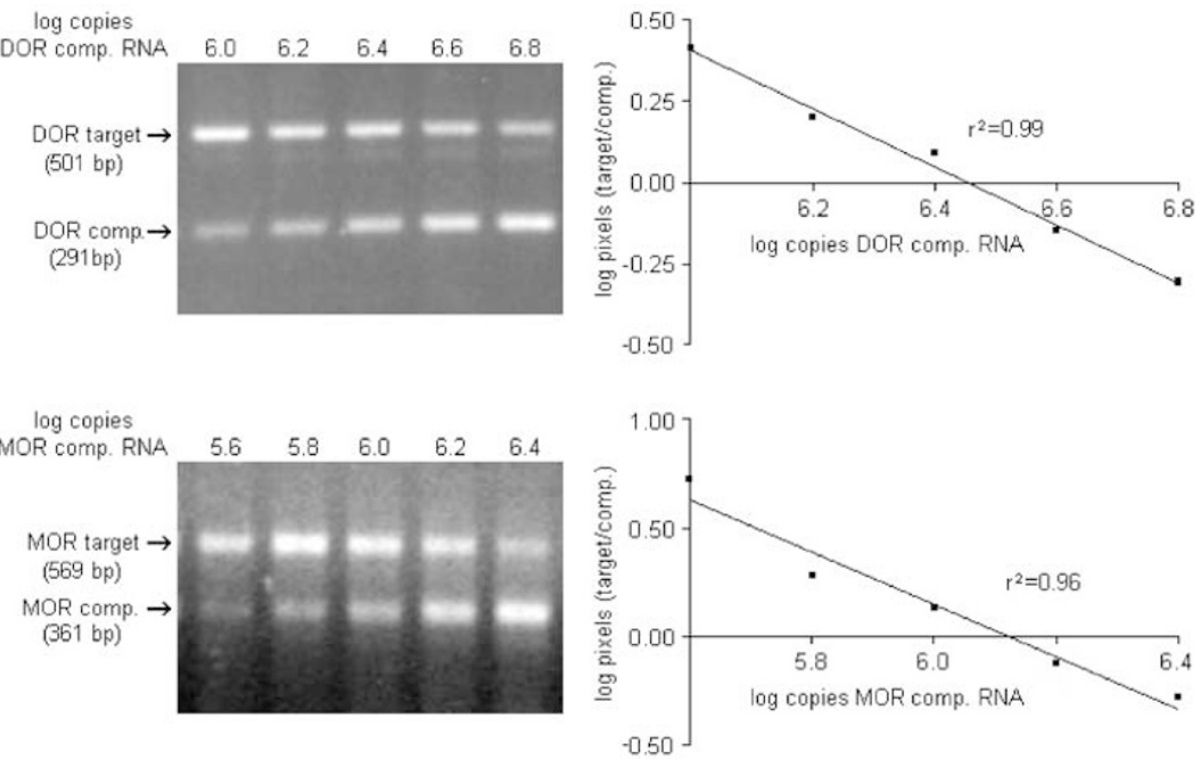

Figure 3 Quantitative competitive RT-PCR analysis. Left panel: Representative photographs of $2 \%$ agarose gels of the PCR products obtained from competitive RT-PCR. Each lane corresponds to one of the five RT-PCR reactions carried out per RNA sample, containing increasing amounts of competitor RNA. Right panel: Linear regression obtained from the densitometric analysis of the target and competitor PCR bands. The $x$ intercept corresponds to the log of the copies of target RNA present in the RNA sample. Upper panel, DOR mRNA in NAcSh; lower panel, MOR mRNA in VTA.
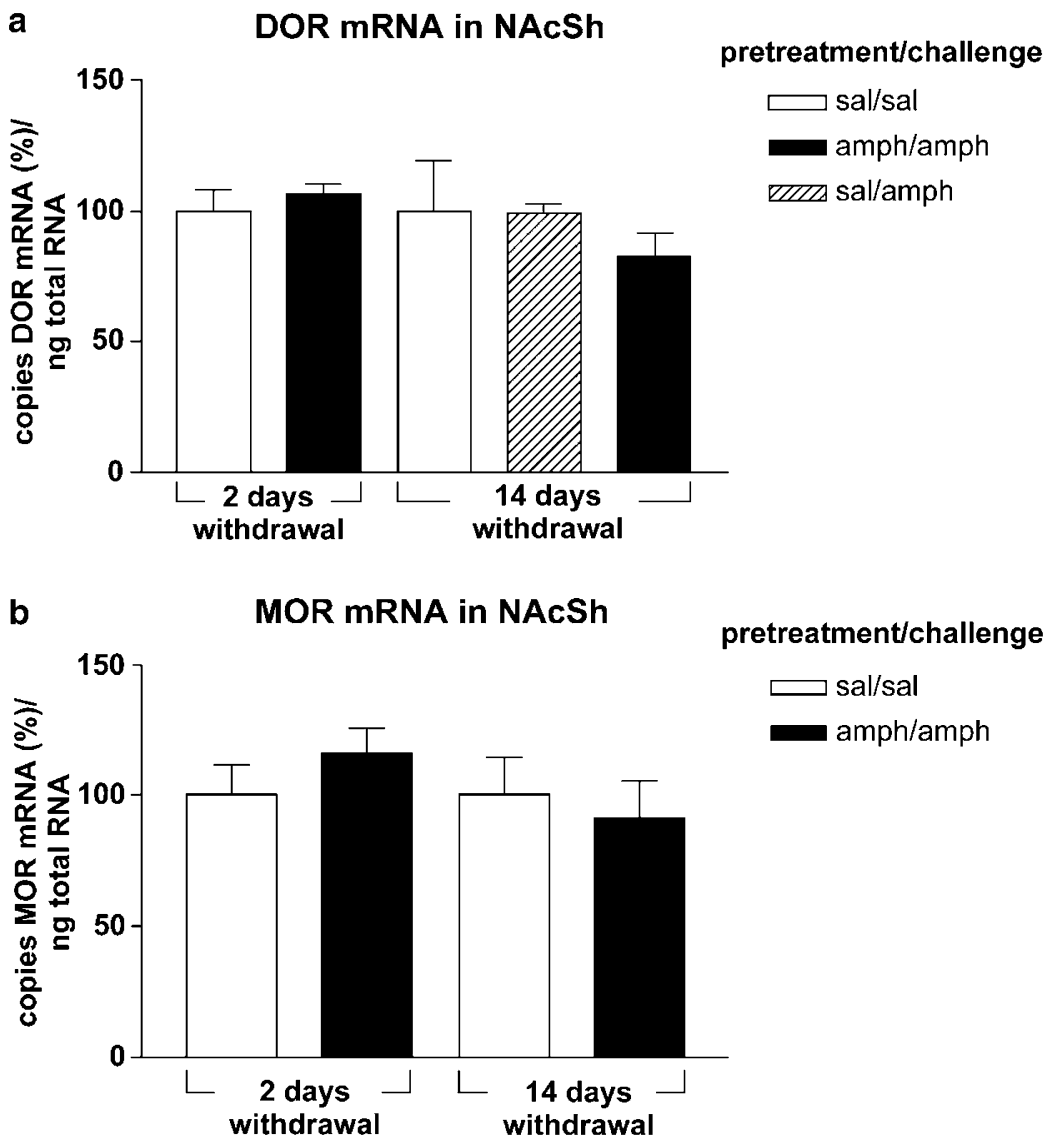

Figure 4 DOR and MOR mRNA levels in the NAcSh of rats expressing behavioral sensitization after 2 and I 4 days of withdrawal. Values are expressed as mean ( \pm SEM) percentage of copies of DOR (a) or MOR (b) mRNA measured after a challenge injection of sal or amph administered 2 or 14 days after pretreatment regime consisting of four injections of saline or amphetamine administered once every other day. Copies of mRNA were determined by competitive quantitative RT-PCR. 
a pretreatment/challenge

$\square \mathrm{sal} / \mathrm{sal}$

amph/amph

ZIII sal/amph

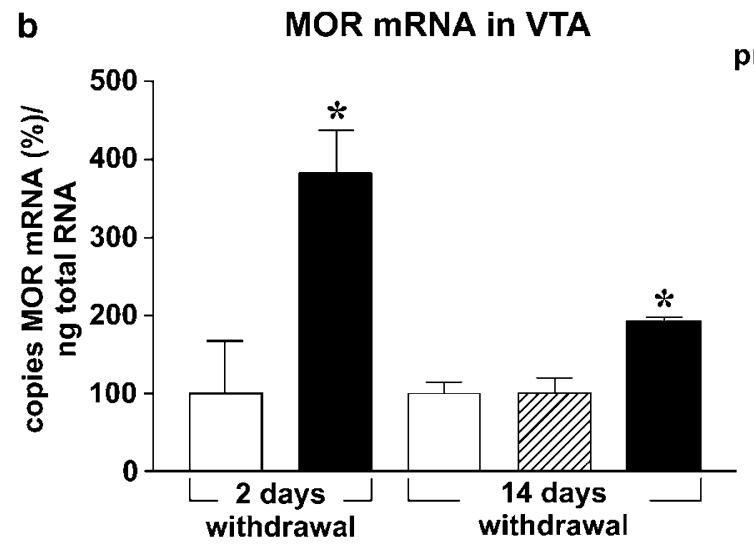

pretreatment/challenge

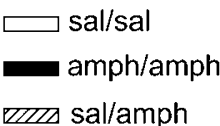

Wms sal/amph

Figure 5 DOR and MOR mRNA levels in the VTA of rats expressing behavioral sensitization after 2 and I 4 days of withdrawal. Values are expressed as mean ( \pm SEM) percentage of copies of DOR (a) or MOR (b) mRNA measured after a challenge injection of sal or amph administered 2 or 14 days after pretreatment regime consisting of four injections of saline or amphetamine administered once every other day. Copies of mRNA were determined by competitive quantitative RT-PCR. *p $<0.05$.

$n=4, p<0.05 ;$ Figure $5 \mathrm{~b}$; copies MOR mRNA $(\%) / \mathrm{ng}$ total RNA, sal/sal, $100+66.1, n=3 ;$ amph/amph, 382.4+54.8, $n=4 ; p<0.05)$.

The increase in amphetamine-induced DOR mRNA was transient, returning to control levels when sensitization was tested 14 days after withdrawal (Figure 5a; copies DOR mRNA (\%)/ng total RNA, sal/sal, $100+21.5, n=5$; sal/amph, $59.57+36.0, n=3$; amph/amph, $107.5+11.8, n=4)$. On the other hand, the levels of MOR mRNA remained elevated when sensitization was tested 14 days after withdrawal (Figure 5b; copies MOR mRNA (\%)/ng total RNA, sal/sal, $100+14.0, n=4 ; \mathrm{sal} / \mathrm{amph}, 101.2+17.8, n=4 ; \mathrm{amph} / \mathrm{amph}$, 192.6+4.7, $n=4 ; p<0.05)$.

\section{DISCUSSION}

This study shows that an initial four every-other-day exposure to amphetamine induced behavioral sensitization, which was expressed following a challenge amphetamine injection administered 2 or 14 days after withdrawal. Naloxone did not modify the expression of behavioral sensitization when tested 2 days after withdrawal. In contrast, the expression of behavioral sensitization tested after 14 days of withdrawal was completely blocked by the opioid antagonist.
The analysis of MOR and DOR mRNA expression showed that DOR and MOR mRNA levels in the NAcSh were not modified in response to a challenge amphetamine injection administered after 2 or 14 days of drug discontinuation. On the other hand, DOR and MOR mRNA levels were elevated in the VTA of animals expressing behavioral sensitization after 2 days of withdrawal. However, whereas DOR mRNA returned to control levels, MOR mRNA levels remained elevated in the VTA of animals expressing behavioral sensitization after 14 days of withdrawal.

\section{Behavioral Studies}

Our results indicate a striking difference between the role played by opioid receptors in the expression of amphetamine-induced behavioral sensitization, when tested 2 or 14 days after drug withdrawal. While locomotor sensitization to amphetamine is expressed at each of these test times, numerous lines of evidence show that the accompanying neuronal events are different (Pierce and Kalivas, 1997). For example, the manifestation of augmented dopamine transmission depends on the time after discontinuing the sensitization drug treatment regimen. During the first week of withdrawal, no change, decreases and increases in the ability of stimulants to elevate extracellular dopamine levels have been observed in the NAc and striatum of the 
rat (Pierce and Kalivas, 1997). After more lengthy withdrawal periods (two or more weeks), increased dopamine transmission is consistently associated with the expression of behavioral sensitization (Pierce and Kalivas, 1997).

Our observation that the expression of behavioral sensitization is not blocked at short-term withdrawal periods is consistent with that of Heidbreder et al (1996), which shows that the administration of naltrindole, a DOR antagonist, does not block the expression of behavioral sensitization when given 2 days after cocaine pretreatment.

In this study we show that naloxone does not alter locomotor activity in response to an amphetamine challenge injection administered to saline-pretreated animals. This observation argues against the possibility that naloxoneinduced blockade of the expression of behavioral sensitization tested after 14 days of withdrawal results from a generalized disruption of behavior.

\section{Expression Studies}

In order to investigate whether changes in opioid receptor mRNA levels could account for the difference in the role played by opioid receptors in the expression of behavioral sensitization tested after short- or long-term withdrawal periods, the levels of MOR and DOR MRNA were quantified in the NAcSh and VTA. In the present study we report no changes in MOR mRNA levels in the NAcSh of rats expressing behavioral sensitization tested after 2 days of abstinence. These results are consistent with those of Unterwald et al (2001) which, using RNase-protection assay (RPA), reported that intermittent cocaine administration produces a transient increase in MOR mRNA levels in the NAc of rats after the first injection day, returning to basal levels after 7 or 14 days of binge-pattern cocaine administration. However, we have previously reported, using quantitative in situ hybridization (ISH), a significant decrease in MOR mRNA in the NAcSh of rats expressing behavioral sensitization following repeated intermittent administration (Vecchiola et al, 1999).

This discrepancy may be explained by the existence of neuronal heterogeneity within the NAcSh. When using RTPCR and RPA methodologies, the quantification corresponds to the levels of mRNA expressed in the entire NAcSh, which must be dissected out for RNA extraction and analysis. On the other hand, when using the method of ISH, the quantification corresponds to mRNA levels expressed on discrete regions of the NAcSh. Thus, if the NAcSh is a neuroanatomically heterogeneous brain nucleus, the levels of DOR or MOR mRNA expressed by a discrete set of neurons may differ from the net DOR or MOR mRNA levels expressed in the whole nucleus.

In this report we show that both DOR and MOR mRNA levels were elevated in the VTA of rats expressing behavioral sensitization when tested after short-term drug withdrawal. However, whereas DOR mRNA returned to control levels, MOR mRNA levels remained elevated in the VTA of animals expressing behavioral sensitization after 14 days of withdrawal. This is the first study, to our knowledge, that shows long-lasting effects of amphetamine-induced MOR expression.
It is generally accepted that the processes of initiation and expression of behavioral sensitization are not only temporally but also anatomically distinct. Initiation of behavioral sensitization to psychostimulants occurs in the VTA, whereas the neuronal events associated with expression are distributed among the interconnected nuclei of the motive circuit (Pierce and Kalivas, 1997). However, various studies have identified changes in the VTA that may contribute to the expression of behavioral sensitization. Thus, repeated cocaine injections result in long-term changes in the presynaptic regulation of GABA transmission by D1 receptors in the VTA (Bonci and Williams, 1996). Repeated cocaine injections also influence the release of glutamate in the VTA. Thus, cocaine administration enhances extracellular glutamate levels in the VTA of rats pretreated 21 days earlier with daily cocaine (Kalivas and Duffy, 1998). The enhanced releasability of glutamate in the VTA of sensitized rats is consistent with electrophysiological observations that at 10 , but not 2 days after discontinuing repeated amphetamine the excitatory response elicited in dopamine cells by stimulating excitatory amino acid afferents from the PFC is increased (Tong et al, 1995).

The functional significance of the differential amphetamine-induced regulation of MOR and DOR mRNA levels in the VTA of rats expressing behavioral sensitization after short and long periods of withdrawal is not understood. However, the behavioral data using the opioid receptor antagonist naloxone suggest a relation between the amphetamine-induced increase in MOR but not DOR mRNA levels, after 14 days of withdrawal, and the expression of behavioral sensitization at this stage. Further experiments will be necessary to resolve this issue. Nevertheless, our results support the notion that amphetamine-induced changes in opioid receptor expression may contribute to the perpetuation of psychostimulant abuse and/or relapse.

\section{ACKNOWLEDGMENTS}

We are grateful to Dr Marŕa Inés Forray for valuable help with reviewing this manuscript. We thank José Fuentealba and Dr Katia Gysling for advice on the pharmacological studies, Lucy Chacoff for help in preparation of this manuscript, and Jorge Abarca for constant assistance. This work was supported by FONDECYT Grants 2990084 (to $\mathrm{KM}$ ) and 1010986 (to GB).

\section{REFERENCES}

Balcells-Olivero M, Vezina P (1997). Effects of naltrexone on amphetamine-induced locomotion and rearing: acute and repeated injections. Psychopharmacology 131: 230-238.

Bonci A, Williams JT (1996). A common mechanism mediates long-term changes in synaptic transmission after chronic cocaine and morphine. Neuron 16: 631-639.

Búzás B, Cox BM (1997). Quantitative analysis of mu and delta opioid receptor gene expression in rat brain and peripheral tissue using competitive polymerase chain reaction. Neuroscience 76: 479-489.

Cador M, Bjijou Y, Cailhol S, Stinus L (1999). D-amphetamineinduced behavioral sensitization: implication of a glutamatergic 
medial prefrontal cortex-ventral tegmental area innervation. Neuroscience 94: 705-721.

Churchill L, Kalivas PW (1996). Dopamine-opioid interactions in the basal forebrain. In: Ashby Jr CR (ed). The Modulation of Dopaminergic Neurotransmission by other Neurotransmitters. CRC Press: Boca Raton, FL. pp 55-86.

Devine DP, Leone P, Pocock D, Wise RA (1993). Differential involvement of ventral tegmental mu, delta and kappa opioid receptors in modulation of basal mesolimbic dopamine release: in vivo microdialysis studies. J Pharmacol Exp Ther 266: 12361246.

Di Chiara G, Imperato A (1988). Opposite effects of mu and kappa opiate agonists on dopamine release in the nucleus accumbens and in the dorsal caudate of freely moving rats. J Pharmacol Exp Ther 244: 1067-1080.

Di Chiara G, North RA (1992). Neurobiology of opiate abuse. Trends Pharmacol Sci 13: 185-193.

Feigenbaum JJ, Howard SG (1997). Effects of naloxone on amphetamine induced striatal dopamine release in vivo : a microdialysis study. Life Sci 60: 1659-1668.

Garzon M, Pickel VM (2001). Plasmalemmal mu-opioid receptor distribution mainly in non dopaminergic neurons in the rat ventral tegmental area. Synapse 41: 311-328.

Gracy KN, Svingos AL, Pickel VM (1997). Dual ultrastructural localization of mu-opioid receptors and NMDA-type glutamate receptors in the shell of the rat nucleus accumbens. J Neurosci 17: 4839-4848.

Heidbreder C, Shoaib M, Shippenberg TS (1996). Differential role of delta-opioid receptors in the development and expression of behavioral sensitization to cocaine. Eur J Pharmacol 298: 207216.

Kalivas PW, Alesdatter JE (1993). Involvement of N-methyl-Daspartate receptor stimulation in the ventral tegmental area and amygdala in behavioral sensitization to cocaine. J Pharmacol Exp Ther 267: 486-495.

Kalivas PW, Duffy PJ (1998). Repeated cocaine administration alters extracellular glutamate in the ventral tegmental area. Neurochemistry 70: 1497-1502.

Kalivas PW, Pierce RC, Cornish J, Sorg BA (1998). A role for sensitization in craving and relapse in cocaine addiction. $J$ Psychopharmacol 12: 49-53.

Karler R, Calder LD, Bedingfield JB (1994). Cocaine behavioral sensitization and the excitatory amino acids. Psychopharmacology (Berl) 115: 305-310.

Karler R, Calder LD, Chaudhry IA, Turkanis SA (1989). Blockade of 'reverse tolerance' to cocaine and amphetamine by MK- 801 . Life Sci 45: 599-606.

Kuzmin AV, Gerrits MA, van Ree JM, Zvartau EE (1997). Naloxone inhibits the reinforcing and motivational aspects of cocaine addiction in mice. Life Sci 60: PL257-PL264.

Mansour A, Fox CA, Akil H, Watson SJ (1995). Opioid-receptor mRNA expression in the rat CNS: anatomical and functional implications. Trends Neurosci 18: 22-29.

Mansour A, Khachaturian H, Lewis ME, Akil H, Watson SJ (1988). Anatomy of CNS opioid receptors. Trends Neurosci 11: 308-314.

Martin G, Nie Z, Siggins GR (1997). mu-Opioid receptors modulate NMDA receptor-mediated responses in nucleus accumbens neurons. J Neurosci 17: 11-22.

Menkens K, Bilsky EJ, Wild KD, Portoghese PS, Reid LD, Porreca F (1992). Cocaine place preference is blocked by the delta-opioid receptor antagonist, naltrindole. Eur J Pharmacol 219: 345-346.

Ohmori T, Abekawa T, Muraki A, Koyama T (1994). Competitive and noncompetitive NMDA antagonists block sensitization to methamphetamine. Pharmacol Biochem Behav 48: 587-591.

Pierce RC, Kalivas PW (1995). Amphetamine produces sensitized increases in locomotion and extracellular dopamine preferentially in the nucleus accumbens shell of rats administered repeated cocaine. J Pharmacol Exp Ther 275: 1019-1029.
Pierce RC, Kalivas PW (1997). A circuitry model of the expression of behavioral sensitization to amphetamine-like psychostimulants. Brain Res Brain Res Rev 25: 192-216.

Rawls SM, McGinty JF (2000). Delta opioid receptors regulate calcium-dependent, amphetamine-evoked glutamate levels in the rat striatum: an in vivo microdialysis study. Brain Res 861: 296-304.

Robinson TE, Berridge KC (2000). The psychology and neurobiology of addiction: an incentive-sensitization view. Addiction Suppl 2(Suppl.): S91-S117.

Sala M, Braida D, Colombo M, Groppetti A, Sacco S, Gori E, Parenti M (1995). Behavioral and biochemical evidence of opioidergic involvement in cocaine sensitization. J Pharmacol Exp Ther 274: 450-457.

Schenk S, Valadez A, McNamara C, House DT, Higley D, Bankson MG et al (1993). Development and expression of sensitization to cocaine's reinforcing properties: role of NMDA receptors. Psychopharmacology (Berl) 111: 332-338.

Shippenberg TS, Chefer VI, Zapata A, Heidbreder CA (2001). Modulation of the behavioral and neurochemical effects of psychostimulants by kappa-opioid receptor systems. Ann NY Acad Sci 937: 50-73.

Shippenberg TS, Elmer GI (1998). The neurobiology of opiate reinforcement. Crit Rev Neurobiol 12: 267-303.

Stewart J, Druhan JP (1993). Development of both conditioning and sensitization of the behavioral activating effects of amphetamine is blocked by the non-competitive NMDA receptor antagonist, MK-801. Psychopharmacology (Berl) 110: 125-132.

Svingos AL, Clarke CL, Pickel VM (1998). Cellular sites for activation of delta-opioid receptors in the rat nucleus accumbens shell: relationship with Met5-enkephalin. J Neurosci 18: 923-933.

Svingos AL, Colago EE, Pickel VM (1999). Cellular sites for dynorphin activation of kappa-opioid receptors in the rat nucleus accumbens shell. J Neurosci 19: 1804-1813.

Svingos AL, Garzon M, Colago EE, Pickel VM (2001). Mu-opioid receptors in the ventral tegmental area are targeted to presynaptically and directly modulate mesocortical projection neurons. Synapse 41: 221-229.

Svingos AL, Moriwaki A, Wang JB, Uhl GR, Pickel VM (1996). Ultrastructural immunocytochemical localization of mu-opioid receptors in rat nucleus accumbens: extrasynaptic plasmalemmal distribution and association with Leu5-enkephalin. $J$ Neurosci 16: 4162-4173.

Tong ZY, Overton PG, Clark D (1995). Chronic administration of (+)-amphetamine alters the reactivity of midbrain dopaminergic neurons to prefrontal cortex stimulation in the rat. Brain Res 674: 63-74.

Unterwald EM (2001). Regulation of opioid receptors by cocaine. Ann NY Acad Sci 937: 74-92.

Unterwald EM, Cox BM, Kreek MJ, Cote TE, Izenwasser S (1993). Chronic repeated cocaine administration alters basal and opioidregulated adenylyl cyclase activity. Synapse 15: 33-38.

Unterwald EM, Cuntapay M (2000). Dopamine-opioid interactions in the rat striatum: a modulatory role for dopamine $\mathrm{D} 1$ receptors in delta opioid receptor-mediated signal transduction. Neuropharmacology 39: 372-381.

Unterwald EM, Horne-King J, Kreek MJ (1992). Chronic cocaine alters brain mu opioid receptors. Brain Res 584: 314-318.

Unterwald EM, Kreek MJ, Cuntapay M (2001). The frequency of cocaine administration impacts cocaine-induced receptor alterations. Brain Res 900: 103-109.

Unterwald EM, Rubenfeld JM, Kreek MJ (1994). Repeated cocaine administration upregulates kappa and $\mathrm{mu}$, but not delta, opioid receptors. Neuroreport 5: 1613-1616.

Vanderschuren LJ, Kalivas PW (2000). Alterations in dopaminergic and glutamatergic transmission in the induction and expression of behavioral sensitization: a critical review of preclinical studies. Psychopharmacology (Berl) 151: 99-120. 
Vecchiola A, Collyer P, Figueroa R, Labarca R, Bustos G, Magendzo K (1999). Differential regulation of mu-opioid receptor mRNA in the nucleus accumbens shell and core accompanying amphetamine behavioral sensitization. Brain Res Mol Brain Res 69: 1-9.

White FJ, Kalivas PW (1998). Neuroadaptations involved in amphetamine and cocaine addiction. Drug Alcohol Depend 51: 141-153.

Wolf ME (1998). The role of excitatory amino acids in behavioral sensitization to psychomotor stimulants. Prog Neurobiol 54: 679-720.

Wolf ME, Dahlin SL, Hu XT, Xue CJ, White K (1995). Effects of lesions of prefrontal cortex, amygdala, or fornix on behavioral sensitization to amphetamine: comparison with $N$-methyl-Daspartate antagonists. Neuroscience 69: 417-439.

Wolf ME, Jeziorski M (1993). Coadministration of MK-801 with amphetamine, cocaine or morphine prevents rather than transiently masks the development of behavioral sensitization. Brain Res 613: 291-294.
Wolf ME, Khansa MR (1991). Repeated administration of MK-801 produces sensitization to its own locomotor stimulant effects but blocks sensitization to amphetamine. Brain Res 562: 164-168.

Wolf ME, Xue CJ (1998). Amphetamine and D1 dopamine receptor agonists produce biphasic effects on glutamate efflux in rat ventral tegmental area: modification by repeated amphetamine administration. J Neurochem 70 : 198-209.

Wolf ME, Xue CJ (1999). Amphetamine-induced glutamate efflux in the rat ventral tegmental area is prevented by $\mathrm{MK}-801, \mathrm{SCH}$ 23390, and ibotenic acid lesions of the prefrontal cortex. $J$ Neurochem 73: 1529-1538.

Wolf ME, Xue CJ, Li Y, Wavak D (2000). Amphetamine increases glutamate efflux in the rat ventral tegmental area by a mechanism involving glutamate transporters and reactive oxygen species. J Neurochem 75: 1634-1644.

Xue CJ, Ng JP, Li Y, Wolf ME (1996). Acute and repeated systemic amphetamine administration: effects on extracellular glutamate, aspartate, and serine levels in rat ventral tegmental area and nucleus accumbens. J Neurochem 67: 352-363. 